\title{
Sporidiobolus salmonicolor
}

National Cancer Institute

\section{Source}

National Cancer Institute. Sporidiobolus salmonicolor. NCI Thesaurus. Code C127748.

A species of yeast-like fungus in the phylum Basidiomycota. The asexual form of S.

salmonicolor is characterized by pink, ballistosporic yeast that are forcibly ejected into the air upon maturity. This species is considered an opportunistic fungal pathogen of immunocompromised individuals. 